\title{
Analysis of the Marketing Margin of Soyabeans in Benue State, Nigeria
}

\author{
Udeh Monica, Christopher Elaigwu Ogbanje, Olotu Olafemi Ayopo
}

\author{
Department of Agribusiness, Federal University of Agriculture, Makurdi.
}

Corresponding author. Email: udehmonica@ymail.com

Tel: 07065022133 .

\begin{abstract}
The study examined the marketing margin of soyabeans marketers in Benue State, Nigeria. A sampling frame of 914 registered soyabeans marketers was obtained from soyabeans marketers association in the study area. Stratified random sampling techniques was employed to obtain 278 market actors (producer-marketers, wholesalers and retailers) for the study. Data were collected with the use of a well structured questionnaire and analyzed using descriptive and inferential statistics. The result on market conduct, showed that all the respondents $(100 \%)$ agreed that they sold their soyabeans immediately after harvest, they rely on family or personal savings for business finance, they do not advertise their soyabeans for sell and they have not attended any training on soyabeans. The result further showed a marketing margin of $\$ 88.91, \$ 85.78$ and $\$ 85.99$ respectively. The major problems faced by soyabeans marketers in the study area include inadequate capital, high transportation cost, lack of access to credit facilities, heavy imposition of taxes or levies and poor storage and warehousing facilities. It was recommended that soyabeans marketers in the study area should form cooperative society to have access to loan from both formal and informal sources for better capital base and higher output. In conclusion soyabeans marketing is a profitable and efficient business, with attractive net return on investment in the study area.
\end{abstract} Keywords-Analysis; soyabeans marketing; marketing margin; Benue State.

\section{INTRODUCTION}

Soyabeans, a member of the family leguminoceae, subfamily papiplonaceae, and the genus Glycine $\max (\mathrm{L})$ Merril, is an annual food legume and an important food, livestock feed, oil, milk production and cash crop in the world. It has been the dominant oilseed produced since the 1960s and is used as human food; medicals, and for various industrial purposes (Adedoyin et al., 1998).

One of the major food problems in Nigeria is the gross deficiency in protein intake, both in quantity and quality
(Dashiell, 1998). Although, protein in human diet is derived from both plant and animal sources, the declining consumption of animal protein due to its high prices requires alternative sources. Soyabeans provides a cheaper and high protein rich alternative substitute to animal protein. It is an important crop in the world and has been the dominant oilseed since the 1960s (Smith and Huyser, 1987). It is a multipurpose crop and its importance ranges from its use in milk production, oil processing, livestock feeds, medical, industrial and human consumption and more recently, as a source of bio-energy (Adedoyin et al., 1998, Myaka et al., 2005). Soyabeans is the richest source of plant protein known to man (Odusanya, 2002). It is also an important source of income.

According to the United State Department of Agriculture, USDA attaché report (2008) Nigeria domestic production of soyabeans is continuing to trend upwards but still does not meet the rapidly growing demand from the poultry and vegetable oil producers. This deficit cause the price of soyabeans to double within eight months and peak at $\$ 1,100$ per ton in august 2008.This high price severely impacted poultry and soyabeans meal import are raising. The rapid growth in the poultry sector in the past 5 years which is about $39 \%$ per annum has boosted demand for soyabeans meal in Nigeria. However, although domestic production has been unable to satisfy local demand, in addition soybean crushers in the country are also operating below capacity and are unable to satisfy the growing demand for vegetable oil estimated at about 300,000tonnes annually.

The Nigerian National Commission on Agriculture defines agricultural marketing as a process which starts with a decision to produce a saleable farm commodity and it involves all aspects of market structure and systems both functional and institutional, based on pre-harvest and postharvest operations, assembling, grading, storage, transportation and distribution (Agricultural Marketing Resource Centre, 2007). 
Research development and investment effort have often been focused on primarily on production increases without a welldeveloped marketing system which leads to all possible gains from the production effort going into the drains of postharvest losses. Often times, marketers are compelled if not forced to sell their product at a very low price to avoid huge wastage or total loss and this reduces their marketing margins and marketing efficiency.

As important as marketing is, most of the studies on soyabeans have concentrated on production (Adekunle, et al. 2003; Abu 2012; Shalma; 2014; Agada 2015. Since proper marketing of soyabeans is made available to all and sundry and even though there have been a few scholarly investigation into soyabeans marketing in Benue State not much has been done on the profitability of soyabeans marketing in Benue State Nigeria. It is against this background that the research was carried out.

\section{Objectives of the Study:}

i. determine the conduct of soyabeans marketers in Benue State;

ii. examine the marketing margin of soyabeans marketing actors in the study area;

iii. Identify the problems faced by soyabeans marketers in the study area.

\section{Statement of Hypothesis}

There was no significant difference in the marketing margin of soyabeans marketers in Benue State.

\section{METHODOLOGY}

\section{Area of study}

The area of this study is Benue State of Nigeria. Benue state was created in 1976 and is located in the middle belt region of Nigeria with the capital at Makurdi. Benue state lie approximately between latitudes $6^{0} 30^{\prime} \mathrm{N}$ and $8^{0} 10^{\prime} \mathrm{N}$ of the equator and longitudes $6^{0} 35^{\prime} \mathrm{E}$ and $8^{0} 10^{\prime} \mathrm{E}$ of the Greenwich meridian, [Benue State Agricultural and Rural Development Authority, (BNARDA), 2005].

Benue state is considered as one of the hottest States in Nigeria with an average minimum and maximum temperature of $21^{\circ} \mathrm{C}$ and $38^{\circ} \mathrm{C}$ respectively. It is in the southern guinea savannah ecological zone, which has a typical climate with the clearly marked seasons of dry season (late October to March) and wet season (April to early October). The State annual rainfall ranges from $1700 \mathrm{~mm}$ in the southern part to $120 \mathrm{~mm}$ in the northern ecology of the state.

The important feature of the state is the river in which the state derived its name from. The state share boundaries with five States, Nassarawa to the North, Taraba to the East, Cross-River to the Southeast Enugu to the Southwest and
Kogi to the west. The southern part of the state is also bounded with republic of Cameroun.

Benue State has a land mass of about $33,955 \mathrm{~km}^{2}$ with 23 Local Government Areas. Geographically and agriculturally, Benue State is divided into three zones, Zone A (katsina-Ala, Ukum, Ushongo, Vandiekya, Logo Kwande and Konshisha local government areas) Zone B (Gboko, Tarka, Buruku, Gwer East , Gwer West, Guma and Makurdi Local government areas), Zone C (Ado , Agatu, Apa, Otukpo, Ohimini, Okpokwu, Ogbadibo, Obi and Oju local government areas).

The state has a total population of 4,219,244 million people (National Population Commissions 2006). About $80 \%$ of the state population is directly involved in agriculture. It is also called the food basket of nation, because the state produces agricultural products in large quantities. Some farmers in the study area have taken poultry production as their source of livelihood.

\section{Population and Sampling Procedure.}

The population of the study comprised all soyabeans traders in Benue State, with particular interest on producer marketers, retailers and wholesalers. The sampling frame of 914 registered soyabeans marketers was obtained from soyabeans Marketers Association in Benue State. Stratified random sampling technique was used to select respondents for this study. Three strata were used for this study. This includes producer marketer wholesaler and retailers. Yamene (1967) formula was used to determine the sample size (278) as follows:

$$
n=\frac{N}{1+N(e)^{2}}
$$

where:

$\mathrm{n}=$ sample size

$\mathrm{N}=$ population

$\mathrm{e}=$ level of significance $(0.05)$

Bowley's proportional allocation technique was used to determine the total sample size that was drawn from each of the selected Local Government Areas. The determination of the sample to be drawn from each LGA was done with the aid of Bowley (1926) formula as follows:

Where:

$$
n_{h=} \frac{n \times N_{h}}{N}
$$

$\mathrm{n}_{\mathrm{h}}=$ Number of unit to be allocated to each stratum

$\mathrm{n}=$ Total sample size

$\mathrm{N}_{\mathrm{h}}=$ Total number of elements in each stratum

$\mathrm{N}=$ Total population of the study

The total number of units drawn from Tarka Local Government Area was 87, 57 and 24 for producer marketers, wholesalers and retailers respectively while that of Konshisha was 59, 38 and 13 for producer marketers 
Table.1: Sample Size Determination

\begin{tabular}{|l|l|l|l|l|l|l|}
\hline LGA & $\begin{array}{l}\text { Producer } \\
\text { marketers }\end{array}$ & & Wholesalers & & Retailers & \\
\hline & $\mathrm{Nh}$ & $\mathrm{nh}$ & $\mathrm{Nh}$ & $\mathrm{nh}$ & $\mathrm{Nh}$ & $\mathrm{nh}$ \\
\hline TARKA & 287 & 87 & 188 & 57 & 79 & 24 \\
\hline KONSHISHA & 194 & 59 & 124 & 38 & 42 & 13 \\
\hline
\end{tabular}

Source: Soyabeans Marketers Association in Benue State, 2016.

\section{Data collection and Analysis}

Data for this study was collected from primary sources. The primary data was generated by the researcher through the use of trained enumerators, personal interview techniques and a well structured questionnaires which was administered to 278 soyabeans marketers in Benue State. 277 questionnaire were retrieved and used in data analysis. Data collected were analysed using descriptive and inferential statistics. The descriptive statistics were frequency distribution, percentages and mean while the inferential statistics were marketing margin model, Analysis of variance, Duncan multiple range test and one-way ANOVA was used to test the hypothesis.

\section{Model Specification}

Marketing Margin Analysis

Marketing margin $=\frac{\text { selling price }- \text { supply price }}{\text { selling price }} \times 100$

Net Marketing Margin was estimated using the formular:

$\mathrm{NMM}=\mathrm{GM}-\mathrm{TMC}$

NMM= Net Marketing Margin (Naira)

$\mathrm{GM}=$ Gross Margin (Naira)

TMC $=$ Total Marketing Cost (Naira)

$1 \mathrm{bag}$ of soyabeans is equivalent to $100 \mathrm{~kg}$

\section{Garrett's ranking technique}

Problem associated with soyabeans marketing was achieved using Garrett ranking technique this was used by Nirmala and Suhasini (2013) as specified below:

$$
\text { percent position }=\frac{100(R i j-0.50)}{N i j}
$$

where,

Rij is the rank given by ith item by jth individual;

$\mathrm{Nij}$ is the number of items ranked by the jth individual

\section{RESULTS AND DISCUSSION}

\section{Market Conduct for Soyabeans in Benue State}

The distribution of respondent according to market conduct is shown in Table 2. The result revealed that all the respondent $100 \%$ indicated their soyabeans was sold at lower prices during the harvest season since there is much soyabeans in the market. Most producer marketers sell their soyabeans during the harvesting season to meet pressing domestic needs. This is because most of them are small holder farmers with little financial capacity. This result agrees with Onu and Iliyasu (2008) that high proportions of grain sales by producers take place during harvest period.

Furthermore, the percentage distributions of respondents by advertising showed that $100 \%$ of the respondents in the study area do not advertise their soyabeans to prospective buyers. This is because the market is structured in a way that sellers can take their soyabeans to particular stalls or position in the market where the middlemen either buy and sell or buy for some companies. This result is in agreement with earlier findings by Abah (2015) that $96.95 \%$ of paddy rice marketers in Benue State do not advertise their paddy rice to prospective buyers.

More so, the distribution of respondents by source of business finance showed that majority $67.9 \%$ depends on personal funding, $22.4 \%$ source their money from family and friends while $9.7 \%$ source their money from bank for their business. Therefore, the table further suggested that, majority of the marketers attracting about $67.9 \%$ employed personal savings to finance their soyabeans marketing business. This may have the tendency to restrict their marketing activities and retard the expansion of the enterprise since capital is the main incentive by which marketers expand their marketing business. This result is in consonance with that of Fadipe et al. (2015) who found that high proportion $(50 \%)$ cocoyam marketers use personal savings as their source of income in sagamu local government area of Ogun State.

Conversely, all the respondent $100 \%$ in the study area have not attended training on soyabeans cultivation or soyabeans marketing. This indicates that there is no research and development practice in soyabeans market in Benue State. This study contradicts earlier study by Abah (2015) that there is free of charge training to rice famers by government extension services and OLAM in Benue State. 
Table.2: Market Conduct of Soyabeans in Benue State $(n=277)$

\begin{tabular}{llll}
\hline Parameter & Frequency & Percentage & $(\%)$ \\
\hline $\begin{array}{l}\text { Price of soyabeans is higher at harvest } \\
\text { season }\end{array}$ & 0 & \\
Yes & 277 & 100 \\
No & &
\end{tabular}

\section{Advertisement}

Yes

No

\section{Financial policy}

Personal savings

Banks

Family and friends

Total

\section{Attended training}

Yes

No
0
100

Source: Computed from field survey data, (2017).

\section{Marketing Margin of Soyabeans Marketers in Benue State}

The marketing margin of soyabeans marketers was presented in Table 3. The result showed that on the average the marketing margin of soyabeans marketers were $\$ 88.91$, $\$ 85.99$ and $\$ 85.78$ per $100 \mathrm{~kg}$ bag for producer marketers wholesaler and retailers, respectively. In Table 3 the calculated average marketing margins for producer marketers is higher than that of retailers and wholesalers. The estimated margins for wholesalers and retailers were correspondingly low. The low level of the average marketing margin of the marketers is largely attributed to the exploitative activities of the agents. This finding contradicts Jongur and Ahmed (2008) who found that farmers margin was as high as $96.81 \%$ and the remaining $31.19 \%$ went to the middlemen involved in sorghum marketing in Adamawa central zone.

Table.3: Marketing Margin of Soyabeans Marketers in Benue State ( $n=277)$

\begin{tabular}{llllll}
\hline Variables & $\mathrm{n}$ & Mean & Std. deviation & Minimum & Maximum \\
\hline & & & & & 75.031 \\
Retailers & 37 & 85.78 & 3.414 & 68.566 & 91.437 \\
Wholesalers & 94 & 85.99 & 4.076 & 74.174 & 99.22 \\
Producer & 146 & 88.91 & 3.739 & & \\
marketers & & & & & \\
\hline
\end{tabular}

Source: Computed from field survey data, 2017.

\section{Result of Hypothesis}

Differences in the Marketing Margin of Soyabeans Marketing Actors in Benue State.

One-way ANOVA was used to determine the marketing margin of the market participants in Table 4. The result shows that $(\mathrm{F}=21.029 ; \mathrm{P} \leq 0.00)$. The $\mathrm{F}$ statistics was significant at $5 \%$ therefore the null hypothesis which state that there is no significance difference in the marketing margin of the marketing actors is rejected and the alternative hypothesis accepted. The Duncan multiple range test indicated that producer marketers had the highest marketing margin ( $\$ 88.91)$ followed by wholesalers (\$85.99), while retailers had the least marketing margin of (\$85.78). The difference in the marketing margin of the respondents is largely attributable to the exploitative activities of middlemen. This finding agrees Achike and Anzaku (2010) that significant difference existed in marketing margins among benniseed traders in Nassarawa State, Nigeria. 
Table.4: Difference in the Marketing Margin of Soyabeans Marketing Actors in Benue State.

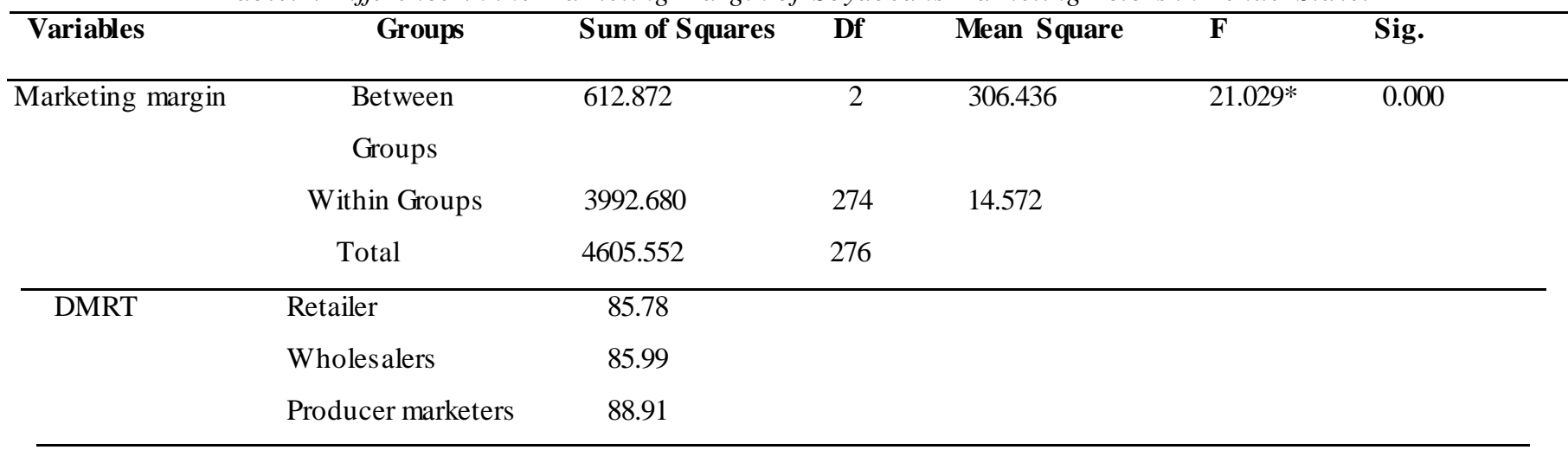

* denotes statistically significance at $5 \%$ level

DMRT: Duncan multiple range test

Source: Computed from field survey data, 2017

Constraints Associated with Soyabeans Marketing in Benue State

As contained in Table 5 which indicated the problems associated with soyabeans marketing in the study area, it reveals that, high transportation cost, poor storage/warehousing facilities, lack of access to credit, debt management or bad debt, heavy imposition of taxes or levies lack of insurance against theft and fire, seasonality, robbery, inadequate capital and adulteration were some of the problem identified as militating against soyabeans marketing in the study area.

Among all the problems inadequate capital was ranked first with a mean of 88.46. This was as a result of inadequate sources of finance and the problem of collateral before obtaining loan. Lack of access to credit facilities and High transportation cost was ranked $2^{\text {nd }}$ with a mean of 85.07 , this maybe as a result of poor road network linking the rural soyabeans markets to the urban centres.. The $4^{\text {th }}$ ranked problem was heavy imposition of taxies or levies. With a mean of 85.03. Poor storage and warehousing facilities ranked the $5^{\text {th }}$ with a mean of 84.13 . The $6^{\text {th }}$ ranked problem was lack of insurance against theft and fire with a mean of 79.83. Robbery /theft ranked $7^{\text {th }}$ with a mean of 30.28 . The 8 ranked problems was seasonality with a mean of 24.60 while debt management/bad debt and adulteration with a mean of 16.04 and 10.77 ranked 9 and 10 respectively. Amongst all, the problems inadequate capital, high transportation cost and heavy imposition of taxes and levies ranks the first three major problems. The combine effect of these problems on the marketing system could bring about a distortion in the structure, conduct and performance of the marketing process. Hence, this could lead to the reduction in profit margin of the marketers and consequently, discourage the present and prospective marketers of the commodity in participating in the enterprise in the study area. These findings were in agreement with that of Girei et al. (2013) in their study of cowpea marketing that inadequate capital, high cost of transportation, inadequate and poor storage facilities, high taxes were the major problems facing cowpea marketers in North and Yola South Local Government Areas in Adamawa State, Nigeria,

\begin{tabular}{lcc}
\multicolumn{2}{c}{ Table.5: Constraints Associated with Soyabeans Marketers in Benue State $(n=277)}$. \\
Variables & Mean & Rank \\
\hline High transportation cost & 85.07 & 2 \\
Poor storage/ warehousing facilities & 84.13 & 5 \\
Lack of access to credit facilities & 85.07 & 2 \\
Debt management or bad debt & 16.04 & 9 \\
Heavy imposition of taxes or levies & 85.03 & 4 \\
Lack of insurance against fire and theft & 79.83 & 6 \\
Seasonality & 24.60 & 8 \\
Robbery/theft & 30.27 & 7 \\
Capital intensive & 88.46 & 1 \\
Adulteration & 10.77 & 10 \\
\hline
\end{tabular}

Source: Computed from field survey data, 2017 


\section{CONCLUSION}

The study showed that soyabeans marketing was profitable in Benue State, Nigeria. The profit level was relatively sustainable and can even attract new entrants into business. Hence, it serves as a source of income and employment for the marketers. The major problems of soyabeans marketing in the study area include inadequate capital, high transportation, lack of access to credit facilities heavy imposition of taxes or levies and poor storage and warehousing facilities.

\section{Recommendation}

I. Efforts should be made to eliminate the constraints to soyabeans marketing in the study area by improving on socioeconomic facilities such as roads, markets stores and related amenities.

II. Government and nongovernmental organization can do their own part by renovating existing bad roads and constructing new ones, especially those that link the points of production to points of consumption.

III. The business can also help in generating jobs and reducing poverty.

IV. Existing association of soyabeans marketers should be strengthen financially by the government through provision of minimal and interest free loans whereas formation of new ones be encouraged by the marketers.

\section{REFERENCES}

[1] Abah, D. A, Abu, G. A. and Ater, P. I. (2015). Analysis of the Structure and Conduct of Paddy Rice Marketing in Benue State, Nigeria .American Journal of Marketing Research 1(2): 70-78.

[2] Abu, G.A. (2012). Comparative productivity under special crop programme in Benue State,

Nigeria: A case of participant and non-participant soyabean growers. Journal of Cereals and Oil seeds Vol. 3(4), pp. 48-55.

[3] Achike, I.A and Anzaku, T.A.K (2010). Economic analysis of the marketing margin of Benniseed in Nasarawa state, Nigeria. Agro-Science Journal. 9(1):47-55

[4] Adekunle, O. A., OgunLade, I. and Oladele, O.I. (2003). Adoption of soybeans production technology in Kwara State, Nigeria. Journal of Extension System, 19 (2): $32-3$.

[5] Adedoyin, S.F.,Torimiro, D.D.,Joda, A.O. and Ogunkoya, A.O. (1998). Adoption of Soybeans Planting, Processing and Utilisation Packages in Ago Iwoye, Proceeding of the 3rd Annual National
Conference of the Agricultural Extension Society of Nigeria, pp4-6

[6] Agada, M.O. (2015).Constraints to Increasing Soybean Production and Productivity in Benue State, Nigeria. Asian Journal of Agricultural Extension, Economics \& Sociology 4(4): $\quad$ 277-284

[7] Agricultural Marketing Resource Centre (2007).Valueadded Agricultural Resource Profile, Iowa State University.

[8] Benue Agricultural and Rural Development Authority BNARDA, (1998). Crop Area and yield Survey, Report by Benue Agricultural and Rural Development Authority (BNARDA): 35.

[9] Bowley, A. L. (1926). Measurements of precision attained in sampling. Bull. Int. Stat. Inst., Amsterdam, v.22, p.1-62.

[10] Dashiell, K. (1998). An Effort to Promote the Production and Consumption of Soybean as a Means of Improving Nutrition in Nigeria.

[11] Fadipe A. E. A., Adenuga, A. H. and Ilori, T.E (2015). Analysis of cocoa marketing in sagamu Local Government Area of Ogun State, Nigeria. Trakia Journal of Sciences, No 3, pp 208-213.

[12] Girei, A.A. Dire, B. Salihu, M. and Iliya, M. M.(2013). Assessment of Problems Affecting the Structure, Conduct and Performance of Cowpea Marketing in Yola North and Yola South Local Government Areas in Adamawa State, Nigeria. British Journal of Marketing Studies 1(4):41-50.

[13] Jongur, A.A.U. and Ahmed, B. (2008). Distribution efficiency of soybean marketing in selected areas of Adamawa central zone of Nigeria. Bowen Journal of Agriculture, 5 (1\&2): 63-71.

[14] Myaka, F. A., Kirenga, G., and Malema, B. (Eds). (2005). Proceedings of the First National Soyabeans Stakeholders Workshop, 10th-11th November 2005, Morogoro Tanzania.

[15] Nirmala, B. and Suhasini, K. (2013). Farmer's experience with hybrid rice technology: A case study of Khunti district of Jharkhand State of India . Directorate of Rice Research, Hyderabad, India. Department of Agricultural Economics, College of Agriculture, ANGR Agricultural Univeristy, Hyderabad, India.

[16] NPC, (2006). National Population Commission. National Population Census, Federal Republic of Nigeria official gazette, 94 (4) Lagos, Nigeria.

[17] Odusanya, R. (2002). Powerful benefits of soybeans: Food, beverages and seasonings. Saturday punch (column 1) Nigeria, January 12, P.33. 
[18] Onu, J.I. and Iliyasu, H.A. (2008). An Economic Analysis of the Food Grain Market in Adamawa State, Nigeria, World Journal of Agricultural Sciences 4 (5): 617-622.

[19] Smith, K. and Huyser, W. (1987). World Distribution and Significance of Soybean. In J.R. Wilcox (Ed.) Soybean: Improvement, Production and Uses. Third Ed. Agron. Monograph. 16. ASA, CSSA, and SSSA, Madison. Pp 1-22.

[20] Yamane, T. (1967). Statistics, An Introductory Analysis, $2^{\text {nd }}$ Ed. New York: Harper and Row. 